\title{
Adhesion to patient safety protocols in emergency care units
}

\author{
Adesão aos protocolos de segurança do paciente em unidades de pronto atendimento \\ Adhesión a los protocolos de seguridad del paciente en unidades de pronta atención
}

\section{Danieli Parreira da Silva Stalisz da Paixão', Josemar Batista', Eliane Cristina Sanches Maziero', Francine Taporosky Alpendre', Marly Ryoko Amaya', Elaine Drehmer de Almeida Cruz'}

' Universidade Federal do Paraná, Postgraduate Program in Nursing. Curitiba, Paraná, Brazil.

How to cite this article:

Paixão DPSS, Batista J, Maziero ECS, Alpendre FT, Amaya MR, Cruz EDA. Adhesion to patient safety protocols in emergency care units. Rev Bras Enferm [Internet]. 2018;71(Suppl 1):577-84. [Thematic Issue: Contributions and challenges of nursing practices in collective health] DOI: http://dx.doi.org/10.1590/0034-7167-2017-0504

\section{Submission: 07-12-2017 Approval: 10-22-2017}

\begin{abstract}
Objective: To investigate compliance of national patient safety protocols in Emergency Care Units (UPA) of the Paraná State. Method: From April until September 2016, the exploratory stage of the action research was conducted on stratified sampling with 377 patients of eight units, with use of verification instrument of basic safety actions. Results: The absence of systematic identification of patients, fall risk assessment and signaling and development of pressure injuries were evidenced. We observed that $52.8 \%$ of parenteral solutions in use were not identified and that, in only $29.4 \%$ of the cases, the allergic condition was investigated. In $80.6 \%$ of the emergency units there was availability of alcoholic solution to hand hygiene. Conclusion: We concluded that the non-compliance of basic actions concerning patient safety exposes users to preventable adverse events and demands systematized actions to comply with government guidelines and promote quality of health assistance.
\end{abstract}

Descriptors: Patient Safety; Emergency Medical Services; Health Care Quality; Checklist; Nursing.

\section{RESUMO}

Objetivo: Investigar o cumprimento dos protocolos nacionais de segurança do paciente em Unidades de Pronto Atendimento paranaenses. Método: Entre abril e setembro de 2016 foi realizada etapa exploratória de pesquisa ação, em amostra estratificada de 377 pacientes de oito unidades, utilizando-se instrumento de verificação de ações básicas de segurança. Resultados: Evidenciou-se ausência de identificação sistematizada dos pacientes e de avaliação e sinalização do risco para queda e desenvolvimento de lesão por pressão. Observou-se que 52,8\% das soluções parenterais em uso não estavam identificadas e que, em apenas 29,4\% dos casos, a condição alérgica foi investigada. Em 80,6\% dos pontos de assistência havia a disponibilidade de solução alcoólica para a higienização das mãos. Conclusão: Conclui-se que o não cumprimento de ações básicas relativas à segurança do paciente expõe os usuários a eventos adversos preveníveis e demanda ações sistematizadas para observância das diretrizes governamentais e promoção da qualidade da assistência em saúde.

Descritores: Segurança do Paciente; Serviços Médicos de Emergência; Qualidade da Assistência à Saúde; Lista de Checagem; Enfermagem.

\section{RESUMEN}

Objetivo: Investigar el cumplimiento de los protocolos nacionales de seguridad del paciente en Unidades de Pronta Atención paranaenses. Método: Entre abril y septiembre de 2016 fue realizada la etapa exploratoria de la investigación acción, en muestra estratificada de 377 pacientes de ocho unidades, utilizándose instrumento de certificación de acciones básicas de seguridad. Resultados: Se evidenció la ausencia de identificación sistematizada de los pacientes y de evaluación y señalización del riesgo para caída y desarrollo de lesión por presión. Se observó que el 52,8\% de las soluciones parenterales en uso no estaban identificadas y que, en solamente el 29,4\% de los casos, la condición alérgica fue investigada. En el 80,6\% de los puntos de asistencia había disponibilidad de solución alcohólica para la higienización de las manos. Conclusión: Se concluye que el no cumplimiento de acciones básicas relativas a la seguridad del paciente 
expone a los usuarios a eventos adversos prevenibles y demanda acciones sistematizadas para la observancia de las directrices gubernamentales y la promoción de la cualidad de la asistencia en salud.

Descriptores: Seguridad del Paciente; Servicios Médicos de Urgencia; Cualidad de la Asistencia a la Salud; Listado de Chequeo; Enfermería.

\section{CORRESPONDING AUTHOR Danieli Parreira da Silva Stalisz da PaixãoＥ-mail: d_enf@yahoo.com.br}

\section{INTRODUCTION}

In Brazil, due to demographic, epidemiological and social transitions, and expressive search for health care in urgent and emergency services, the need to regulate and redirect the health care for users emerged. In this sense, between 2003 and 2009, the National Policy of Health Care to Emergencies (Política Nacional de Atenção às Urgências) was formulated, structured and implanted. Between its components, there are the Emergency Care Units (UPA - Unidades de Pronto Atendimento) directed by the principles of the Brazilian Unified Health System ${ }^{(1)}$.

The UPA are health establishments of intermediate complexity between the basic health care and the hospital network, with uninterrupted operation ${ }^{(2)}$. The volume and complexity of health care, in these units, progress with the increase in urban violence of the country, as well as with population ageing, leading to health care for users affected by heart and cerebrovascular diseases, traumas and victims of external causes ${ }^{(3)}$.

The work process, in these environments, is tied to the performance of innumerable procedures, with continuous interruptions of the activities, and to the overload of work, conditions that reflect the quality of health care provided ${ }^{(4)}$. Other factors are added to it, such as shortage of material and physical resources and operational processes for health care $^{(5)}$, which impair the safety of users, potentially incurring in adverse events, i.e., incidents that harm the patient, and from errors, negligence, failures and omissions of health care process ${ }^{(6)}$.

Systematic review identified the occurrence of $0.16 \%$ to $6.0 \%$ of adverse events in emergency services; between $36 \%$ and $71 \%$ were considered preventable $\mathrm{e}^{(7)}$. In UPA context, we observed the innumerous adverse events, such as: error in administration of drugs, fall, bronchoaspiration, limb mutilation and cranioencephalic trauma, and deaths, usually related to the structural frailties and work process recommended for safe health care ${ }^{(5)}$. Thus, simple and effective actions, through compliance of specific protocols and adoption of safety barriers in the health care system, can prevent situations of risk and adverse events ${ }^{(8)}$.

The evaluation of the structure, process and results of the health system, have been used for a long time in the context of quality and patient safety. In Brazil, the National Patient Safety Program (PNSP - Programa Nacional para a Segurança do Paciente), released in 2013, was an important initiative and included guidebooks of inspection and evaluation of basic safety actions. These are tools to identify potential damages to safety and contribute to the quality of health care of public and private network services ${ }^{(9)}$.

In Brazil, the legal determinations defined by ordinances of the Prosecution Office 354/2014, and 2095 of 2013 define actions directed to safety in health care in the context of urgencies and emergencies. The guidelines to promote safety and avoid errors arising from health care are compiled in Patient Safety Basic Protocols (Protocolos Básicos para a Segurança do Paciente) and are directed to patient identification, hand hygiene promotion, safe surgery performance, pressure injury and fall prevention; and safety in prescription, use and administration of drugs ${ }^{(10-12)}$. Such documents are directed to all health services, according to recommendations of the National Patient Safety Foundation, which emphasizes to still be incipient what it is known on patient safety outside the hospital environment ${ }^{(13)}$.

We consider that the emergency scenario is a critical environment of potential risks to patients, regarding the characteristics of the health care, seriousness of the clinical cases and increase of damages to health due to external causes. Thus, regarding the public policies to promote patient safety, the use of inspection guidebooks is recommended, such as care checklists and relevance of using protocols to guide the health care in UPA.

\section{OBJECTIVE}

To investigate the compliance of national patient safety protocols in UPA of Paraná State.

\section{METHOD}

\section{Ethical aspects}

Data collection was preceded by signing of the informed consent form by the user of the service, or his/her companion, guaranteeing the ethical principles and the priority of health care. The project was approved by the Research Ethics Committee in the Health Science Sector of the Federal University of Paraná and by the Research Ethics Committee of the Local Government of Curitiba.

\section{Study design, location and period}

It is the exploratory stage of an Action Research carried out from April to September 2016, in the eight UPA of the Paraná's capital administered by the municipality. Data were collected based on observation and feedback from users under health care service; search of information in medical records (printed or electronic) and application of the Braden scale.

Population or sample and inclusion and exclusion criteria Users over 18 years old, in emergency rooms, under observation and hospitalization in the period of data collection were included in the research. Collection of data was conducted by observing the schedule, previously established by draw, which related UPA with the shifts. More than one day of investigation was necessary in each UPA to reach the number estimated by the sample calculation. Exclusion criterion was the impediment of continuity of observation/feedback due to 
emergency or any other situation that precluded attention to ethical principles in research and that allowed no continuity of data collection in subsequent moment to the impediment.

Table 1 - Sample Calculation per Emergency Care Unit and Sector for checklist application, Brazil, 2016

\begin{tabular}{|c|c|c|c|c|c|}
\hline UPA* & Sector & Mean** & $\%$ & $\begin{array}{c}\text { Sample } \\
\text { per } \\
\text { UPA* }\end{array}$ & $\begin{array}{c}\text { Sample } \\
\text { per } \\
\text { sector }\end{array}$ \\
\hline \multirow[t]{3}{*}{ A } & Emergency & 1046.3 & 35.88 & & 18 \\
\hline & Hospitalization & 481.4 & 16.51 & 51 & 8 \\
\hline & Observation & 1388.4 & 47.61 & & 24 \\
\hline Total UPA* A & & 2916.1 & 13.52 & & \\
\hline \multirow[t]{3}{*}{ B } & Emergency & 1655.8 & 35.84 & & 29 \\
\hline & Hospitalization & 407.1 & 8.81 & 81 & 7 \\
\hline & Observation & 2556.7 & 55.35 & & 45 \\
\hline Total UPA* B & & 4619.5 & 21.42 & & \\
\hline \multirow[t]{3}{*}{$\mathrm{C}$} & Emergency & 894.4 & 32.56 & & 16 \\
\hline & Hospitalization & 322.3 & 11.74 & 48 & 6 \\
\hline & Observation & 1529.9 & 55.70 & & 27 \\
\hline Total UPA* C & & 2746.7 & 12.74 & & \\
\hline \multirow[t]{3}{*}{$\mathrm{D}$} & Emergency & 817.0 & 39.16 & & 14 \\
\hline & Hospitalization & 392.9 & 18.83 & 36 & 7 \\
\hline & Observation & 876.3 & 42.01 & & 15 \\
\hline Total UPA* D & & 2086.3 & 9.68 & & \\
\hline \multirow[t]{3}{*}{ E } & Emergency & 936.4 & 52.63 & & 16 \\
\hline & Hospitalization & 291.8 & 16.40 & 31 & 5 \\
\hline & Observation & 551.0 & 30.97 & & 10 \\
\hline Total UPA* E & & 1779.1 & 8.25 & & \\
\hline \multirow[t]{3}{*}{$\mathrm{F}$} & Emergency & 1024.6 & 49.52 & & 18 \\
\hline & Hospitalization & 335.3 & 16.20 & 36 & 6 \\
\hline & Observation & 709.1 & 34.27 & & 12 \\
\hline Total UPA* F & & 2068.9 & 9.59 & & \\
\hline \multirow[t]{3}{*}{ G } & Emergency & 1081.3 & 39.13 & & 19 \\
\hline & Hospitalization & 489.7 & 17.72 & 48 & 8 \\
\hline & Observation & 1192.3 & 43.15 & & 21 \\
\hline Total UPA* G & & 2763.2 & 12.81 & & \\
\hline \multirow[t]{3}{*}{$\mathrm{H}$} & Emergency & 985.5 & 38.16 & & 17 \\
\hline & Hospitalization & 755.3 & 29.24 & 45 & 13 \\
\hline & Observation & 842 & 32.60 & & 15 \\
\hline Total UPA* H & & 2582.8 & 11.98 & & \\
\hline Overall total & & 21562.5 & 100.00 & 377 & 377 \\
\hline
\end{tabular}

Source: Dados da Pesquisa sistema E-saúde (2015-2016).

Note: * Emergency Care Unit; ** Monthly mean of treatments in the Emergency Care Units administered by the municipality of Curitiba/PR between April 2015 and March 2016.

Information of the E-saúde - Information System of the Local Government of Curitiba/PR were used for sample calculation. The proportionate stratified sampling was conducted in two stages: the first, to define the sampling weight of each UPA and the second, to determine the number of users to be sampled by the health care sector.

Therefore, the population size $(\mathrm{N})$, the proportion of positive assessment regarding patient safety $(\mathrm{p})$, the margin of error $(\mathrm{E})$ and the confidence level $(z)$ were considered. The population size $(\mathrm{N}=21562)$ corresponded to the mean of treatments in emergency, hospitalization and observation sectors of eight UPA (named from A to H), between April 2015 and March 2016. With no previous results concerning the application of inspection guidebooks, $\mathrm{p}=0.5$ was established, 95\% confidence level, and 0.05 margin of error, resulting in sample size of 377 patients, stratified by sector - Table 1 .

\section{Study protocol}

Data collection was guided by verification instrument of basic actions for patient safety in Ambulatory Care, designed based on PNSP protocols and validated by Brazilian specialists ${ }^{(14)}$, which was filled based on information obtained by observation of the user, his/her answers to the feedback and complementary information extracted from his/her medical record.

\section{Results analysis and statistics}

The data fed the Microsoft Office Excel ${ }^{\otimes}$ spreadsheet prepared by researchers, by double data entry, verification and correction of inconsistencies and they were analyzed based on absolute $(\mathrm{f})$ and relative frequencies (\%) for each indicator and by health care sector. The information from medical records and the result of Braden scale application (component of the data collection instrument) were analyzed in addition to safety indicators in drugs, fall and injury.

\section{RESULTS}

There were no exclusions among the 377 participants; a predominance of participants that were female, senior or in treatment in the observation section was evidenced (Table 2).

Table 2 - Characterization of patients in emergency care units, according to sector, sex and age group, Brazil, 2016

\begin{tabular}{llcc}
\hline \multicolumn{2}{c}{ Variables } & $\mathbf{n}$ & $\mathbf{\%}$ \\
\hline Sex & Female & & \\
& Male & 223 & 59.1 \\
& Total & 154 & 40.9 \\
\multicolumn{1}{c}{ Age group } & 377 & 100 \\
& & \\
& & 171 & 45.4 \\
& $\geq 60$ & 206 & 54.6 \\
& Total & 377 & 100 \\
Sector & & \\
& Observation & 169 & 44.8 \\
& Emergency & 147 & 39.0 \\
& Hospitalization & 61 & 16.2 \\
& Total & 377 & 100 \\
\hline
\end{tabular}

The results from five of the six categories of security, are shown in Table 3, according to health care sector. From the 
categories established, the patient identification, signaling the degree of risk to fall and pressure injury, and the identification of solutions administered, and allergy investigation represent the greatest frailties in relation to adhesion to basic actions for patient safety in all sectors.

The higher compliance in the Infection Risk is highlighted - availability of alcoholic solution for hand hygiene of the health team (80.6\% of compliance), and higher frailty in the Patient Identification indicator $(100 \%$ of noncompliance) - Table 3.

Regarding the Surgical Risk indicator, constant on data collection instrument used $^{(14)}$, the absence of patients under care in this specialty was verified. Therefore, this indicator was suppressed in these results.

Table 3 - Indicators of patient safety according to sectors of emergency care units, Brazil, 2016

\begin{tabular}{cccccccccc}
\hline & \multicolumn{2}{c}{ Observation } & \multicolumn{2}{c}{ Emergency } & \multicolumn{2}{c}{ Hospitalization } & Total \\
Indicator & $f$ & $\%$ & $f$ & $\%$ & $f$ & $\%$ & $f$ & $\%$ & $\%$
\end{tabular}

Patient identification

Yes
No
It does not apply
Total

Administration of drugs

Allergic patient

Yes

No

No information

Total

Identified allergen

Yes

No

It does not apply

Total

Identified infusions

Yes

No

It does not apply

Total

Risk of Fall

Degree of risk signaled

Yes

No

Total

Orientation regarding the risk

Yes

No

Total

Elevation of bed bars

Yes

No

It does not apply

Total

$\begin{array}{cc}3 & 1.8 \\ 61 & 36.1 \\ 105 & 62.1 \\ 169 & 44.8 \\ & \\ 2 & 1.2 \\ 1 & 0.6 \\ 166 & 98.2 \\ 169 & 44.8 \\ & \\ 17 & 10.1 \\ 128 & 75.7 \\ 24 & 14.2 \\ 169 & 44.8\end{array}$

4.8
21.1
74.1
39.0

3.4
1.4
95.2
39.0

43.5
40.8
15.6
39.0

21.1

74.1

39.0

3.4

1.4

95.2

39.0

43.5

64

60

23

147
40.8

39.0

-
61
-
61

61

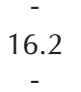

16.2
377

$-$

377
100

100

Infection

Available alcoholic solution

Yes

No

Total

Risk of pressure injury

Risk for injury

Yes

No

Total

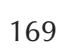

169

40

129

169

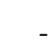

-

169

169

169

$-$

169
100

44.8

23.7

76.3

44.8

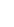

$\begin{array}{ll}- & 107\end{array}$

$-$

100

44.8

147

147

23

124

147

39

147
100

44.8

109

38

147
100

39.0

15.6

84.4

39.0

72.8

26.5

0.7

39.0
0

14.8

85.2

16.2

0

0

100

16.2

67.2

18.0

14.8

16.2

\section{0}

101

266

377

7

3

367

377

122

199

199
56
377

377
2.6

26.8

70.6

100

1.9

0.8

97.3

100

32.4

52.8

14.8

100 


\begin{tabular}{|c|c|c|c|c|c|c|c|c|}
\hline \multirow{2}{*}{ Indicator } & \multicolumn{2}{|c|}{ Observation } & \multicolumn{2}{|c|}{ Emergency } & \multicolumn{2}{|c|}{ Hospitalization } & \multicolumn{2}{|c|}{ Total } \\
\hline & $f$ & $\%$ & $f$ & $\%$ & $f$ & $\%$ & $f$ & $\%$ \\
\hline \multicolumn{9}{|l|}{ Risk signaled } \\
\hline Yes & - & - & - & - & - & - & - & - \\
\hline No & 169 & 100 & 147 & 100 & 61 & 100 & 377 & 100 \\
\hline Total & 169 & 44.8 & 147 & 39.0 & 61 & 16.2 & 377 & 100 \\
\hline \multicolumn{9}{|l|}{ Patient has injury } \\
\hline Yes & 2 & 1.2 & 27 & 18.4 & 6 & 9.8 & 35 & 9.3 \\
\hline No & 167 & 98.8 & 120 & 81.6 & 55 & 90.2 & 342 & 90.7 \\
\hline Total & 169 & 44.8 & 147 & 39.0 & 61 & 16.2 & 377 & 100 \\
\hline
\end{tabular}

\section{DISCUSSION}

Reflecting the sample calculation of this research, most of users that participated were from the observation and emergency sectors, followed by the hospitalization sector. The female sex majority corroborates the profile of the population in the UPA, according to national studies ${ }^{(15-16)}$ and the increased demand of $\geq 60$-years-old users differs from the stated in the study carried out in the Southeast region of Brazil, whose concentration stood between 20 and 39 years old ${ }^{(15)}$, which can be justified by the diverse methodological design, geographical location and sample size of investigations.

In emergency services, the pediatric and geriatric groups fit in the population of greater risk for occurrence of adverse events $^{(7)}$. Considering the increased demand of health care for senior citizens in our survey, and the tendency of population aging in Brazil, the relevance of using guiding protocols for safe execution of professional practice is emphasized. Such measures favor the promotion of actions directed to prevention and reduction of adverse events in emergency and urgency services of the country.

Regarding the safety indicators, based on protocols of the prosecution office, the results indicate that all users had no identification, evidencing the noncompliance to the proposed by the first international goal ${ }^{(16)}$. It is appropriate to highlight that in the UPA of our research, there are systematic identification of users, as recommended by the Brazilian Ministry of Health ${ }^{(17)}$. Even though initiatives to conduct identification were observed, by registering the name and birth date in a sign posted next to the bed. However, such improvised manner is fragile, because the identification is not on the user, which allows exchanges and incurs serious errors.

A Brazilian study ${ }^{(5)}$ identified the absence of use of identification bracelets in UPA, corroborating the results of our research. Safe and standardized identification assisted in error reduction during identification of blood samples, as stated in a Thai study ${ }^{(18)}$. In this context, the blood collection in laboratory tests is also a usual practice in UPA. User identification is fundamental to avoid exchanges of samples and results.

Also, considering the emergency situations in the UPA, we highlight that patient identification since his/her admission is important to avoid occurrence of incidents ${ }^{(19)}$. Other factors amplify the risks, such as alteration in level of consciousness, emphasizing the importance to adopt the aforementioned protocol, which undoubtedly contributes to the provision of care to the proper individual, avoiding possible incidents and errors ${ }^{(17)}$.

Regarding the allergy condition identification on the health care form and/or medical records, among the 10 (2.6\%) documents with such record, three $(0.80 \%)$ did not correspond to the identification or highlight in medical prescription, to alert the health team, as recommended by the Ministry of Health's protocol $^{(17)}$.

Considering the indicator of administration of drugs, we highlight that $70.6 \%(\mathrm{~N}=266)$ of the medical records had no description or any information on presence or absence of allergy, which supposes absence of such investigation. To hypothesize the allergy condition is a practice to be systematized in the medication cycle, since the prescription and dispensation, until the preparation and administration of drugs. We also note the importance of inserting the patient in the care process, inquiring about his/her clinical history, aiming to avoid allergic, adverse and possibly fatal events ${ }^{(20)}$. The units of this research use no alternatives to alert professionals about allergies, being under the patient's responsibility to keep his/ her own safety.

Despite the lower occurrence of allergic condition observed, the adoption of actions to manage risks and prevent incidents and errors are recommended. In this sense, the routine investigation and the record of medical prescription subsidize the nursing care and reduce the chance of dispensation and administration of allergy medication ${ }^{(17)}$.

We observed that most patients $(85.2 \% ; \mathrm{N}=321)$ received intravenous solutions during health care. However, in $52.8 \%$ $(\mathrm{N}=199)$ of the cases the infusions were not identified, a contributing fact to the error, since the identification of the medicine is a basic requirement for safe practices in the medication process $^{(17)}$. Its absence complicates the rapid action of professionals in cases of allergic reactions, because they will need to resort to the medical record to take assertive decisions. In addition to the risk, there is the fact that most of the drugs administered in the UPA are considered of high surveillance, being required a higher precision in its administration ${ }^{(16-17)}$ and compliance of fundamental safety principles, such as identification of the solution in use.

Study conducted in the area of hospital assistance, identified that errors in intravenous administration of medicines drugs have been associated with the absence of drug checking $(96.73 \%)$ and on checking of patients (70.57\%) between 367 
drugs administered ${ }^{(21)}$. The systematized shortage of patient identification, frequency of administration of endovenous medications and insufficient identification of solutions administered in the UPA of our research contribute to the error and explain the difficulties in overcoming the third challenge proposed by the $\mathrm{WHO}^{(22)}$, which refers to the safe administration of medications.

Based on the results, we found that in the UPA investigated there are favorable conditions for the occurrence of adverse events related to the medication process. Considering the possible work overload, interruptions during the preparation of medications and inattention in these health services ${ }^{(23)}$, the risk may be exacerbated.

Regarding the sixth international goal, which consists of the reduction of injuries caused by falls ${ }^{(16)}$, we found that there is no routine assessment of risk for its development. Among users, or their relatives, $75.3 \%(\mathrm{~N}=284)$ had not received guidance on preventive measures; recognized as a commitment of the health team and fundamental measure to avoid damage ${ }^{(24)}$. Considering that one of the risk factors for falls is to be aged over 65 years old ${ }^{(17)}$, and that in this study the predominant age group was $\geq 60$ years old, we reiterate the recommendation of adoption of protocol for the risk assessment, using appropriate instrument ${ }^{(17)}$.

In the observation sector, $76.3 \%(\mathrm{~N}=129)$ of users, accommodated in chairs or armchairs mentioned have not been orientated on preventive measures for falls. A study conducted on a public hospital in the Southeast of Brazil showed that falls of armchair accounted $18 \%$ of notifications, solely lower than the same levels $(64.2 \% \text { of cases) })^{(25)}$.

In this study, among patients accommodated in stretcher/bed, we identified that in the hospitalization sector, $49.2 \%$ of them $(N=30)$ were alerted regarding the risk, diverse result from the observed among the patients in the emergency room, where we identified only $15.6 \%(\mathrm{~N}=23)$ orientated. As an aggravating circumstance, we observed that only $72.8 \%(\mathrm{~N}=107)$ of stretchers/ beds had elevated bars, fact that adds up to the high risk due to type of accommodation, regardless of predictive factors that contribute to the occurrence of this event, as ensured by the Ministry of Health, which also emphasizes the importance to maintain the bars elevated as relevant preventive action ${ }^{(17)}$.

Another safety indicator investigated was related to the infections associated with health care, which corresponds to the fifth international goal for safety ${ }^{(16)}$. In this topic, the availability of alcoholic solution at the point of patient care and the correct hand hygiene are strategies recognized by WHO as gold standard to reduce its occurrence ${ }^{(17)}$. We observed that in $80.6 \%(N=304)$ of sectors, there was availability of alcoholic solution next to the user, emphasizing the observation sector, with full compliance (100\%). This positive result may reflect historical recommendations about the importance of hand hygiene as fundamental action to protect users and workers, and reiterates the importance of continuous education actions to incorporate assertive practices.

The last safety indicator concerns the prevention of pressure injury. In this research, most participants had no risk factor to such adverse event $(64.5 \%, \mathrm{~N}=243)$; however, in the emergency sector, $18.4 \%(N=27)$ of these had injury before the care. We know that the high incidence of pressure injuries in hospitalized critical patients ${ }^{(26)}$ increases proportionally with the combination of risk factors, such as: advanced age and restriction to the bed $^{(17)}$. Thus, in the health care of nonhospital units as well, the identification of users with risk to develop pressure injury, with application of validated predictive scale, associated with clinical assessment by the nurse, allows immediate adoption of preventive measures ${ }^{(17)}$. In our research, we showed there was no risk assessment for this occurrence; however, regarding the prevailing age group of users, we emphasize the relevance of noticing this risk to anticipate the risk, as well as to detect and treat preexisting injuries.

Finally, during data collection, there were no users with surgical risk, result that achieves the ordinance of the prosecution office, which directs the transference of critical patients with surgical nature to hospital service, building a coherent and effective flow, using health regulation centrals ${ }^{(2)}$.

Results between the UPA had no statistical difference, showing that the frailties in relation to patient safety are similar, and can be faced with organizational strategies applicable to all services.

\section{Study limitations}

This research allowed the investigation of adhesion to basic actions to patient safety, except the ones regarding surgical risk. We suggest adequacy of the instrument used in data collection for investigation of safety conditions of other invasive procedures, conducted routinely in the UPA, such as chest drainage and insertion of central venous catheter, and that are risk opportunity to adverse events.

\section{Contributions to the fields of nursing, health, or public policies}

This study demonstrated the importance and viability of the use of inspection guidebooks in the UPA, aiming to identify frailties and establish patient safety indicators, whose results can contribute to the establishment of corrective and preventive actions. Such initiative contributed for the execution of good health practices related to patient safety and supported by the public policies. Moreover, the results of this research arise its replication in other health care scenarios, including basic health care units, because they evidence important frailties in the safety of users in UPA.

\section{CONCLUSION}

The results of our research allow us to evidence the frailty of the work process in relation to patient safety in UPA, characterized as services of medium complexity, high demand of service and fundamental in the health care network in the country. In accordance to the established in security protocols for health services in Brazil, we perceive the need to implement in this units basic and fundamental actions through institutional standards and routines, according to the local reality. Such measures, when systematized, may contribute to reduce potential risks and promote safety and quality in the health work process. To this end, the commitment of public administrators and health professionals in the recognition of such demand in adopting public policies established by the Brazilian Ministry of Health and recommended by international organizations. 


\section{REFERENCES}

1. Machado CV, Salvador FGF, O’Dwyer G. Mobile emergency care service: analysis of Brazilian policy. Rev Saúde Pública [Internet]. 2011 [cited 2017 May 20];45(3):519-28. Available from: http://www.scielo.br/pdf/rsp/v45n3/en_2335.pdf

2. Brasil. Ministério da Saúde. Portaria no 342, de 4 de março de 2013. Redefine as diretrizes para implantação do Componente Unidade de Pronto Atendimento (UPA 24h) e do conjunto de serviços de urgência 24 (vinte e quatro) horas não hospitalares da Rede de Atenção às Urgências e Emergências (RUE), em conformidade com a Política Nacional de Atenção às Urgências, e dispõe sobre incentivo financeiro de investimento para novas UPA 24h (UPA Nova) e UPA 24h ampliadas (UPA Ampliada) e respectivo incentivo financeiro de custeio mensal. Diário Oficial da União 05 mar 2013; Seção1. p. 47.

3. Brasil. Ministério da Saúde. Portaria n 1600, de 07 de julho de 2011. Reformula a Política Nacional de Atenção às Urgências e institui a Rede de Atenção às Urgências no Sistema Único de Saúde (SUS). Diário Oficial da União 08 jul 2011; Seção 1. p. 70.

4. Weigl M, Müller A, Holland S, Wedel S, Woloshynowych M. Work conditions, mental workload, and patient care quality: a multisource study in the emergency department. BMJ Qual Saf [Internet]. 2016 [cited 2016 Sep 12];25:499-508. Available from: http://qualitysafety.bmj.com/content/early/2015/09/08/bmjqs-2014-003744

5. Santos ANS. Segurança do paciente em unidades não hospitalares de atendimento as urgências e emergências: análise de riscos [Dissertação]. Goiânia (MG): Universidade Federal de Goiás; 2015.

6. World Health Organization. WHO. The conceptual framework for the international classification for patient safety v1.1: final technical report and technical annexes [Internet]. 2009 [cited 2016 Sep 20]. Available from: http://www.who.int/patientsafety/ taxonomy/icps_full_report.pdf

7. Stang AS, Wingert AS, Hartling L, Plint AC. Adverse events related to emergency department care: a systematic review. PLoS One [Internet]. 2013 [cited 2016 Mar 16];8(9):e74214. Available from: https://www.ncbi.nlm.nih.gov/pubmedhealth/PMH0059565/

8. Oliveira RM, Leitão IMTA, Silva LMS, Figueiredo SV, Sampaio RL, Gondim MM. Strategies for promoting patient safety: from the identification of the risks to the evidence-based practices. Esc Anna Nery Rev Enferm[Internet]. 2014 [cited 2016 Jan 13];8(4):1229. Available from: http://www.scielo.br/pdf/ean/v18n1/en_1414-8145-ean-18-01-0122.pdf

9. Brasil. Ministério da Saúde. Fundação Oswaldo Cruz. Fiocruz. Agência Nacional de Vigilância Sanitária. Documento de referência para o Programa Nacional de Segurança do Paciente [Internet]. Brasília: Ministério da Saúde; 2014 [cited 2015 Aug 10]. Available from: http://bvsms.saude.gov.br/bvs/publicacoes/documento_referencia_programa_nacional_seguranca.pdf

10. Brasil. Ministério da Saúde. Portaria n. 354 de 10 de março de 2014. Publica a proposta de Projeto de Resolução "Boas Práticas para Organização e Funcionamento de Serviços de Urgência e Emergência". Diário oficial da união 11 mar 2014 ; Seção 1. p. 53.

11. Brasil. Ministério da Saúde. Portaria $n^{\circ} 1.377$, de 9 de julho de 2013. Aprova os protocolos de segurança do paciente. Diário Oficial da União, 10 jul 2013; Seção1. p. 47.

12. Brasil. Ministério da Saúde. Portaria n 2.095, de 24 de setembro de 2013. Aprova os protocolos básicos de segurança do paciente. Diário Oficial da União, 25 set 2013; Seção 1. p. 47.

13. National Patient Safety Foundation. NPSF. Free from Harm: accelerating patient safety improvement fifteen year safer To Err Is Human [Internet]. 2015 [cited 2016 Aug 25]. Available from: http://www.npsf.org/?page = freefromharm

14. Amaya MR, Paixão DPSS, Sarquis LMM, Cruz EDA. Construction and content validation of checklist for patient safety in emergency care. Rev Gaúcha Enferm [Internet]. 2016 [cited 2017 May 06];37(esp):e68778. Available from: http://seer.ufrgs.br/index.php/ RevistaGauchadeEnfermagem/article/viewFile/68778/41287

15. Ferrari R, Loyola AP, Pansani AP, Santos BL, Azeredo DB, Magalhães FAA, et al. Perfil da demanda dos usuários da clínica da família e da UPA em área com 100 \% de cobertura de atenção primária. G\&S [Internet]. 2014 [cited 2016 Jan 10];5(2):525-41. Available from: http://periodicos.unb.br/index.php/rgs/article/view/22781/16329

16. Joint Commission International. JCl. Joint Commission International Accreditation Standards for Hospitals JCI [Internet]. 2014. [cited 2016 Dec 12]. Available from: https://www.jointcommissioninternational.org/assets/3/7/Hospital-5E-Standards-OnlyMar2014.pdf

17. Brasil. Ministério da Saúde. Protocolos básicos de segurança do paciente[Internet]. Brasília: Ministério da Saúde. 2013 [cited 2016 Dec 22]. Available from: http://portalsaude.saude.gov.br/index.php/index.php?option $=$ com_content\&view $=\operatorname{article\& id=28202}$ \&catid $=1243$ \&ltemid $=187$

18. Ning HC, Lin CN, Chiu DTY, Chang YT, Wen CN, Peng SY, et al. Reduction in Hospital-Wide Clinical Laboratory Specimen Identification Errors following Process Interventions: a 10-Year Retrospective Observational Study. PLoS One [Internet]. 2016 [cited 2016 Jan 10];11(8):e0160821. Available from: http://dx.doi.org/10.1371/journal.pone.0160821

19. Smith AF, Casey K, Wilson J, Fichbacher-Smith D. Wristbands as aids to reduce misidentification: an ethnographically guided task analysis. Int J Qual Health Care [Internet]. 2011 [cited 2016 Oct 31];23(5):590-9. Available from: https://doi.org/10.1093/intqhc/mzr045

20. Paranaguá TTB, Bezerra ALQ, Silva AEBC. The occurrence of near misses and associated factors in the surgical clinic of a teaching hospital. Cogitare Enferm [Internet]. 2015 [cited 2016 Jun 08];20(1):121-8. Available from: http://dx.doi.org/10.5380/ce.v20i1.37446 
21. Silva LD, Camerini FG. Analisys the intravenous medication administration in sentinel network hospital. Texto Contexto Enferm [Internet]. 2012 [cited 2017 Jan 10];21(3):633-41. Available from: http://dx.doi.org/10.1590/S0104-07072012000300019

22. World Health Organization. WHO. 66th World Health Assembly: engaging patients in medication safety [Internet]. 2013 [cited 2016 Dec 28]. Available from: http://www.who.int/patientsafety/patients_for_patient/WHA2013_briefing-note.pdf

23. Santi T, Beck CLC, Silva RM, Zeitoune RG, Gollner R, Tonel JZ, et al. Error de medicación en un hospital universitario: percepción y factores relacionados. Enferm Glob [Internet]. 2014 [cited 2017 Jan 10];13:172-83. Available from: http://scielo.isciii.es/pdf/eg/ v13n35/administracion1.pdf

24. Luzia MF, Almeida MA, Lucena AF. Nursing care mapping for patients at risk of falls in the Nursing Interventions Classification. Rev Esc Enferm USP [Internet]. 2014 [cited 2016 Jun 08];48(4):632-9. Available: http://dx.doi.org/10.1590/S0080-623420140000400009

25. Meneguin S, Ayres JA, Bueno GH. Caracterização das quedas de pacientes em hospital especializado em cardiologia. Rev Enferm UFSM [Internet]. 2014 [cited 2017 Jan 10];4(4):784-91. Available from: http://dx.doi.org/10.5902/2179769213554

26. Borghardt AT, Prado TN, Araújo TM, Rogenski NMB, Bringuente MEO. Evaluation of the pressure ulcers risk scales with critically ill patients: a prospective cohort study. Rev Latino-Am Enfermagem [Internet]. 2015 [cited 2016 Jan 10];23(1):28-35. Available from: http://dx.doi.org/10.1590/0104-1169.0144.2521 